\title{
Distribution and abundance of pit vipers (Reptilia: Viperidae) along the Western Ghats of Goa, India
}

\author{
Nitin S. Sawant ${ }^{1}$, Trupti D. Jadhav ${ }^{2}$ \& S.K. Shyama ${ }^{3}$ \\ ${ }^{1}$ Research Scholar, ${ }^{3}$ Associate Professor, Department of Zoology, Goa University, Goa 403206, India \\ ${ }^{2}$ H.No. 359-A, St.Inez, Altinho, Panaji, Goa 403001, India \\ Email: ${ }^{3}$ nitinnature@yahoo.co.in, ${ }^{2}$ truptijadhav2@gmail.com, ${ }^{3}$ shyamask2001@yahoo.co.in.
}

Date of publication (online): 26 September 2010 Date of publication (print): 26 September 2010 ISSN $0974-7907$ (online) | 0974-7893 (print)

Editor: S. Bhupathy

\section{Manuscript details:}

Ms \# o2489

Received 22 June 2010

Final received 30 August 2010

Finally accepted 13 September 2010

Citation: Sawant, N.S., T.D. Jadhav \& S.K. Shyama (2010). Distribution and abundance of pit vipers (Reptilia: Viperidae) along the Western Ghats of Goa, India. Journal of Threatened Taxa 2(10): 1199-1204.

Copyright: ( $)$ Nitin S. Sawant, Trupti D. Jadhav \& S.K. Shyama 2010. Creative Commons Attribution 3.0 Unported License. JoTT allows unrestricted use of this article in any medium for non-profit purposes, reproduction and distribution by providing adequate credit to the authors and the source of publication.

Author Details: NITIN S. SAWANT employed with WWF-India, as State Director of the Goa State office, with responsibilities of designing, planning and executing environmental awareness and conservation programme in the state and to address issues pertaining to environment and wildlife. Actively involved in rescue operations of snakes and other wild animals in association with the forest department of Goa.

TRUPTI D. JADHAV founder member of Nirmiti, a ocal NGO working towards documentation of biodiversity and its conservation. Pursued MSc. in zoology through Goa University. Presently involved in wildlife conservation activities.

DR. S.K. ShYAmA, Associate Professor, Department of Zoology, Goa University.

Author Contribution: NSS and TDJ have contributed in the field work and writing of the manuscript. SKS contributed in the final editing of the manuscript.
Abstract: The distribution and abundance of pit vipers in the Western Ghats namely Trimeresurus gramineus (Bamboo Pit Viper), T. malabaricus (Malabar Pit Viper) and Hypnale hypnale (Hump-nosed Pit Viper) was investigated in five wildlife sanctuaries of Goa from 2005 to 2009. Seasonal day-night data was collected based on band transect methods. All the pit viper species showed specific habitat preferences and their abundance changed with season. They were most abundant during monsoon. $H$. hypnale extended its range to the adjoining cashew plantations during the post monsoon and winter

Keywords: Habitat preference, Hypnale, seasonal variation, Trimeresurus

\section{INTRODUCTION}

Goa $\left(14^{0} 51^{\prime}-15^{\circ} 48^{\prime} \mathrm{N} \& 73^{\circ} 41^{\prime}-74^{0} 20^{\prime} \mathrm{E}\right)$ is a maritime state along the central west coast of Indian peninsula. The Western Ghats of India is one of the 34 biodiversity hotspots in the world (Myer et al. 2000). Goa $\left(3702 \mathrm{~km}^{2}\right)$ occupies about $2 \%$ area of Western Ghats (Joshi \& Janarthanam 2004) and its biodiversity is under threat due to deforestation (Myer 1990; Menon \& Bawa 1997; Jha et al. 2000). Reptilian fauna is largely dominated by the IndoChinese element, relicts India's geological history. Approximately, out of 530 species of reptiles presently reported from India 197 comprises endemics, of these 98 endemics out of 260 species are reported from the Western Ghats (Daniel 2002). In spite of this high endemism, herpetofauna in India has received poor attention and has not been studied in detail (Vasudevan et al. 2001) and it is possible that a few of them have already been lost even before being reported (Dar et al. 2008). Pit vipers belong to the family Viperidae and subfamily Crotalinae, which is represented by 21 genera. Nineteen species of pit vipers have been reported from India (Bhide 2001) including seven from the Western Ghats (Kumar et al. 1998). All these species barring Trimerusurus gramineus are endemic to Western Ghats (Whitaker 1969; Whitaker \& Captain 2004; Khaire 2006). Information on the distribution, abundance and present conservation status of pit vipers in Western Ghats is scanty.

\section{MATERIALS AND METHODS}

The present study was conducted in Mhadei Wildlife Sanctuary (MWS: 208.48km²), Bhagwan Mahaveer Wildlife Sanctuary and National Park (BMWS \& NP: $\left.241 \mathrm{~km}^{2}\right)$, Bondla Wildlife Sanctuary (BWS: $\left.8 \mathrm{~km}^{2}\right)$, Netravali Wildlife Sanctuary (NWS: $211.05 \mathrm{~km}^{2}$ ), Cotigao Wildlife Sanctuary (CWS: $86 \mathrm{~km}^{2}$ ) and in cashew Anacardium occidentale plantations within and adjoining areas of these protected areas (PA) (Fig. 1). Altitude of the study areas ranged from 20 to $800 \mathrm{~m}$ and consists of west coast tropical evergreen, cane brakes, wet bamboo brakes, west coast semi-evergreen, moist bamboo brakes, lateritic semi-evergreen forest, slightly moist teak forest, southern moist deciduous 
forest, southern secondary moist mixed deciduous forest, south Indian subtropical hill savannah woodland and southern subtropical hill forest (Champion \& Seth 1968; Table 1). The ambient temperature usually fluctuates between 15 and $30^{\circ} \mathrm{C}$.

The distribution and abundance of pit vipers was studied in all the PAs mentioned above using band transect following Dahanukar \& Padhey (2005). Surveys were carried out on foot in different seasons (summer - March to May, monsoon - June to October and winter - November to February) during June 2005 to January 2009. Surveys were conducted during both day and night in predetermined paths or roads (2500x20 m). Geographical position of each study area and location of each observation of the snake was recorded using a handheld geographical positioning system (GPS). Relative humidity and ambient temperatures of the observation sites were recorded using a hygrometer and mercury thermometer respectively.
Transects were traversed everyday for a week at each site by the researcher with the help of local volunteers. The transects were repeated five times per season. Visual inspection of shrubs, trees, ground and leaf litter was carried out for locating the snakes. All pit vipers encountered during the surveys were identified up to species level following Smith (1943), Murthy (1990) and Daniel (2002). The individuals were not marked, the snakes sighted on any single transect on successive days were identified based on the scale count and was not included to calculate the abundance. Abundance (number of individuals sighted in each study area) is represented as mean \pm standard error. The mean abundance of the three species in each of the study sites and across seasons (summer, monsoon and winter) was tested to know whether the seasonal variation in each study site has any influence in abundance of the species, using twoway ANOVA.

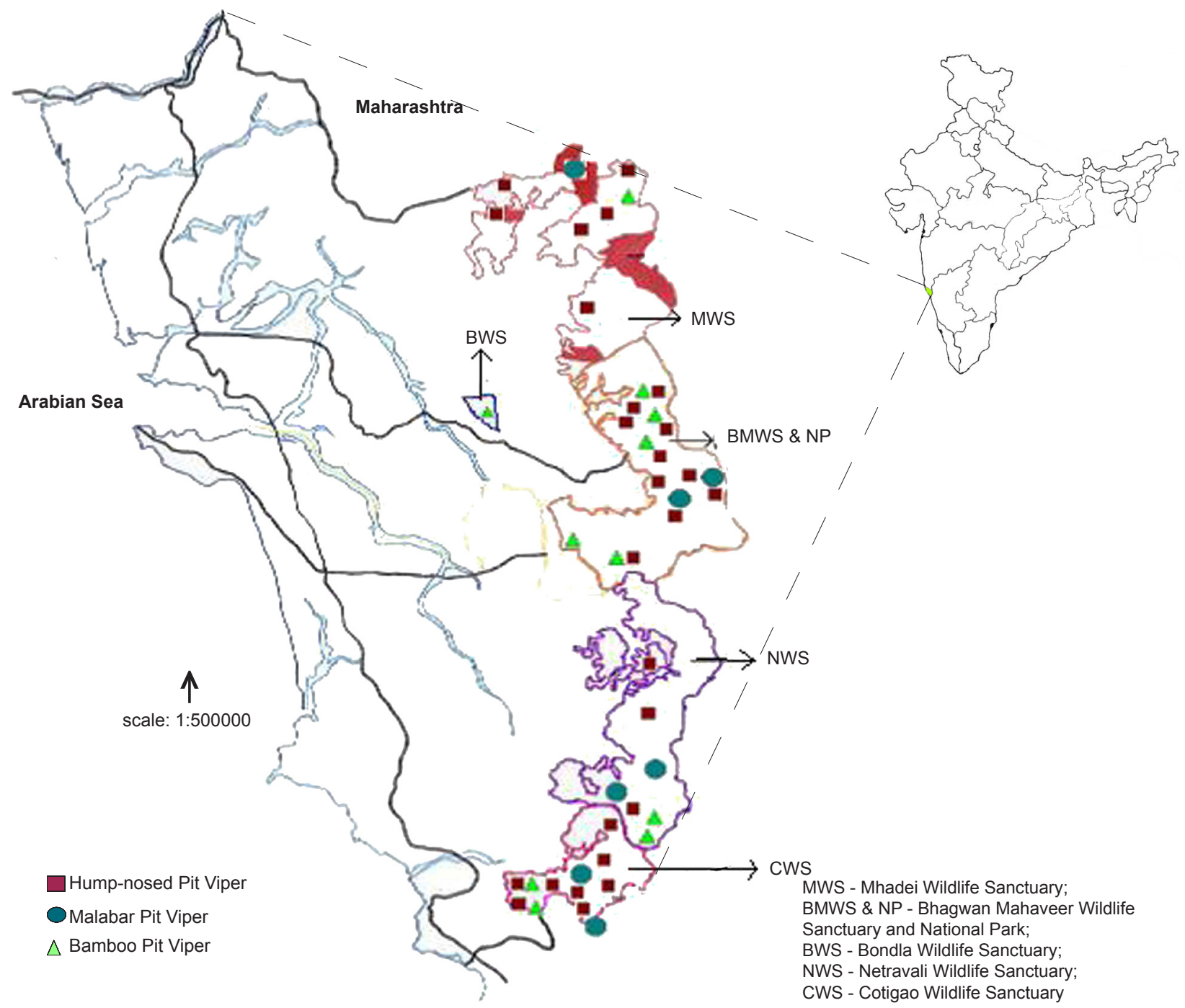

Figure 1. Map of Goa showing the distribution of pit viper species in the study sites 
Table 1. List of forest types present in the study areas.

\begin{tabular}{|l|c|c|c|c|c|}
\hline \multicolumn{1}{|c|}{ Forest type } & \multicolumn{3}{c|}{ Protected Area } \\
\cline { 2 - 6 } & MWS & BWS & BMWS \& NP & NWS & CWS \\
\hline West coast tropical evergreen & $\sqrt{ }$ & & $\sqrt{ }$ & $\sqrt{ }$ & $\sqrt{ }$ \\
\hline Cane brakes & $\sqrt{ }$ & $\sqrt{ }$ & $\sqrt{ }$ & $\sqrt{ }$ \\
\hline Wet bamboo brakes & $\sqrt{ }$ & $\sqrt{ }$ & $\sqrt{ }$ & $\sqrt{ }$ \\
\hline Slightly moist teak forest & $\sqrt{ }$ & & $\sqrt{ }$ & $\sqrt{ }$ \\
\hline Southern moist deciduous forests & & $\sqrt{ }$ & $\sqrt{ }$ & $\sqrt{ }$ \\
\hline South Indian subtropical savannah woodland & $\sqrt{ }$ & & $\sqrt{ }$ & $\sqrt{ }$ \\
\hline Southern subtropical hill forest & & & $\sqrt{ }$ & $\sqrt{ }$ \\
\hline Southern secondary moist mixed forest & $\sqrt{ }$ & $\sqrt{ }$ & $\sqrt{ }$ & $\sqrt{ }$ \\
\hline West coast semievergreen & $\sqrt{ }$ & $\sqrt{ }$ & $\sqrt{ }$ & $\sqrt{ }$ \\
\hline Moist bamboo brakes & $\sqrt{ }$ & $\sqrt{ }$ & $\sqrt{ }$ & $\sqrt{ }$ \\
\hline Lateritic semievergreen forest & $\sqrt{ }$ & $\sqrt{ }$ & & $\sqrt{ }$ \\
\hline
\end{tabular}

\section{RESULTS}

In all, 45 transects (CWS - 7, MWS - 12, NWS - 7, BWS - 4 and BMWS \& NP - 15) were sampled to assess the species distribution and abundance of pit vipers. Three species of pit vipers, T. gramineus, T. malabaricus and $H$. hypnale were recorded during this study (Images $1,2,3)$. A total of 356 pit vipers were observed during this study. $H$. hypnale was the most abundant species contributing $(46.63 \%, \mathrm{n}=166)$ followed by $T$. gramineus $(28.09 \%, n=100)$ and T. malabaricus $(25.28 \%, n=90)$. The abundance of pit vipers varied in different study locations (Table 3).

All three species of pit vipers were observed in all the study locations, except the BWS, where only T. gramineus was found. However, the locals report the presence of $T$. malabaricus in BWS. The forests type preferred by each species of pit vipers is listed in (Table 2). The temperature and humidity of the area during the present study ranged from $20.88 \pm 5.25^{\circ} \mathrm{C}$ to $32.44 \pm 0.88^{\circ} \mathrm{C}$ and $53 \pm 4 \%$ to 93 $\pm 2 \%$ respectively.

T. malabaricus was observed at an altitude above $200 \mathrm{~m}$ and exhibited occurrence at higher elevation in all the sites except in CWS; where it was recorded below $200 \mathrm{~m}$ thus occupying the range between 123 and $765 \mathrm{~m}$. Trimeresurus gramineus and $H$. hypnale were found from 37 to $672 \mathrm{~m}$ and 35 to $672 \mathrm{~m}$ respectively (Fig. 2). T. malabaricus and $T$. gramineus were observed at (mean \& SD) $1.53 \pm 1.6 \mathrm{~m}$ and $1.45 \pm 0.68 \mathrm{~m}$ above ground respectively, whereas, $H$. hypnale was mostly found on the ground (beneath leaf litter), but, occasionally found on shrubs and herbs (up to $0.39 \mathrm{~m}$ ) as well.

Distribution of pit vipers varied among seasons. During monsoon they were found in all 45 transects, whereas, in summer and winter they were observed in 35 transects which include transects having water bodies in the vicinity and transects in the cashew plantations, and were

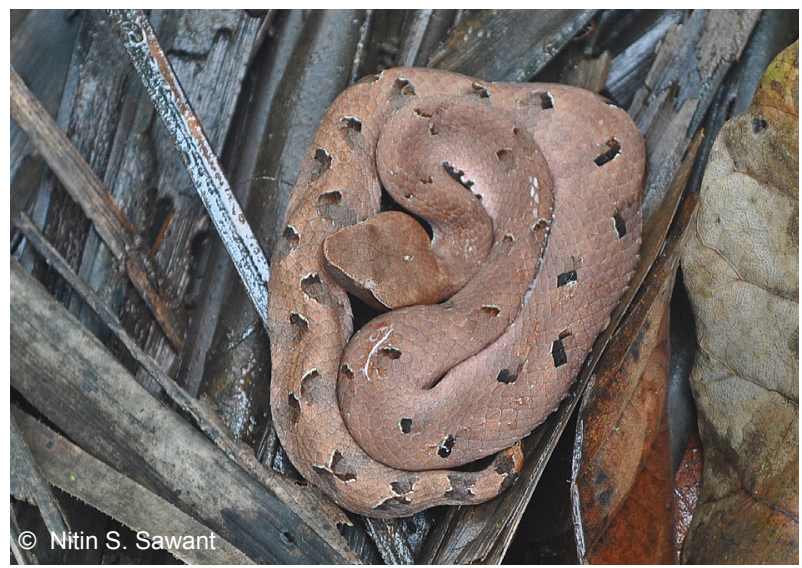

Image 1. Hump-nosed Pit Viper Hypnale hypnale

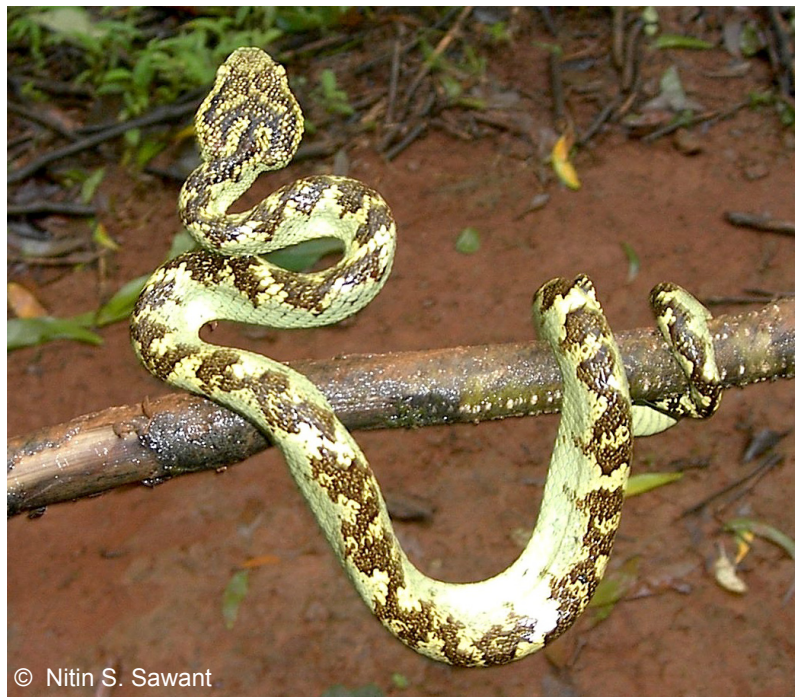

Image 2. Malabar Pit Viper Trimeresurus malabaricus 


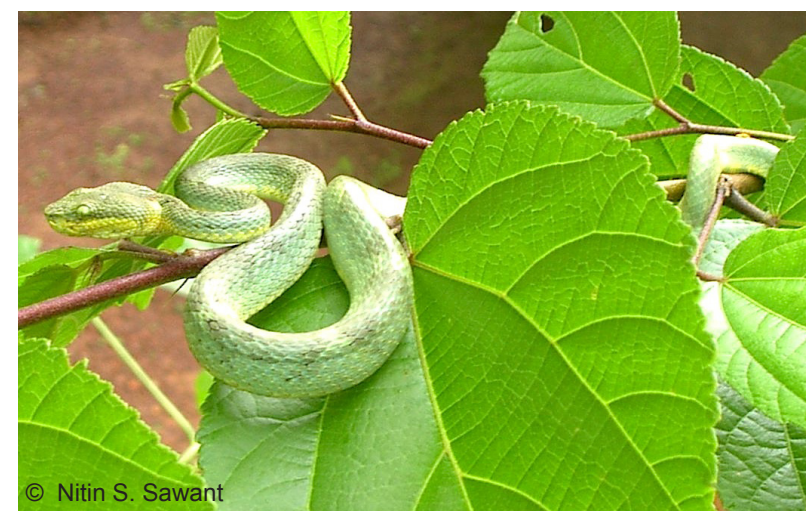

Image 3. Bamboo Pit Viper Trimeresurus gramineus

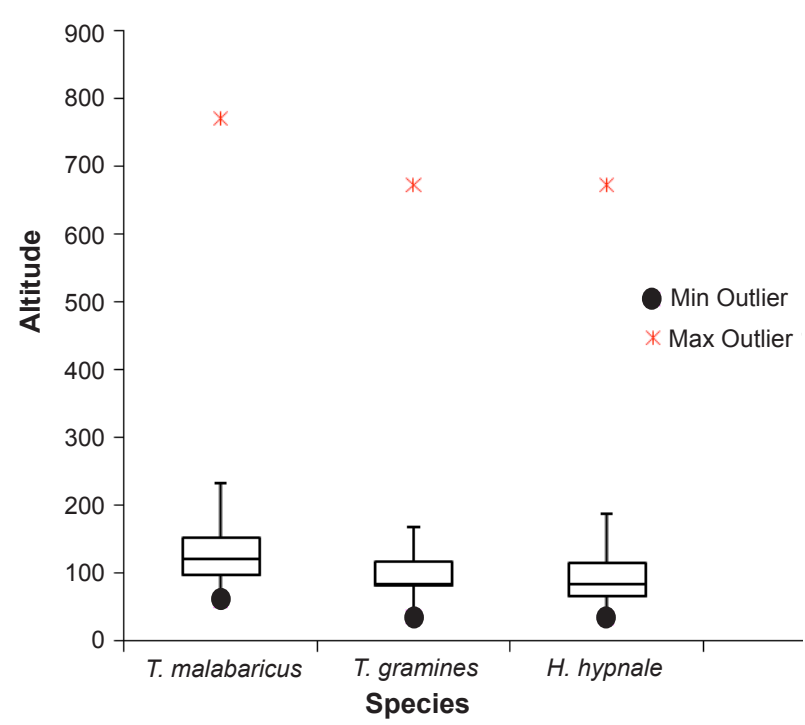

Figure 2. Graph showing mean $\pm \mathrm{SD}$, $\min$ and $\max$ value of altitude (in $\mathrm{m}$ ) at which the pit viper species were observed in Goa restricted to patches near moist areas. H. hypnale moved to adjoining cashew plantations during post monsoons (September and October) and winter, their abundance was high during monsoon in all transects (Table 4). ANOVA showed that the abundance of pit vipers varied significantly with seasons [ $T$. malabaricus $(F=3.20, p=$ $0.00058), T$. gramineus $(F=3.20, p=0.00028)$ and $H$. hypnale $(F=3.20, p=0.015)]$. However, the abundance did not change significantly during each season when compared between sites.

\section{DISCUSSION}

Species in a reptile assemblage are not randomly distributed in space either horizontally or vertically, but occupy discrete microhabitat (Heatwole 1982). The distribution and abundance of all three species of pit vipers varied as their habitat-use was different. The $T$. malabaricus and T. gramineus are arboreal, whereas, $H$. hypnale is terrestrial in nature, however, a semi- arboreal behavior was also observed in $H$. hypnale. The present results augment the report of Murthy (1990). It was observed that most of the pit vipers were encountered in the regions having cool climate (segments of the transects with lower temperature and higher humidity) suggesting that the species prefer cool and moist places. Daltry et al. (1998) reported that the pit vipers typically remain motionless in areas with dense cover of undergrowth, suggesting this species is hygrophilic in nature. The three species remain highly camouflaged in their habitat and move very rarely exhibiting ambush behaviour.

Trimeresurus malabaricus predominantly occupied tropical semievergreen forests and rarely used moist deciduous forests. Trimeresurus gramineus and $\mathrm{H}$. hypnale were observed largely in cane brakes, wet bamboo brakes, tropical semievergreen and moist

Table 2. List of forest types preferred by the pit vipers

\begin{tabular}{|l|c|c|c|}
\hline \multirow{2}{*}{ Forest types } & \multicolumn{3}{|c|}{ Pit viper species } \\
\cline { 2 - 4 } & T. malabaricus & T. gramineus & H. hypnale \\
\hline West coast tropical evergreen & ${ }^{*}$ & ${ }^{*}$ & ${ }^{*}$ \\
\hline Cane brakes & & ${ }^{*}$ & ${ }^{*}$ \\
\hline Wet bamboo brakes & & ${ }^{*}$ & ${ }^{*}$ \\
\hline Slightly moist teak forest & ${ }^{*}$ & ${ }^{*}$ & ${ }^{*}$ \\
\hline Southern moist deciduous forests & ${ }^{*}$ & ${ }^{*}$ & \\
\hline South Indian subtropical savannah woodland & ${ }^{*}$ & ${ }^{*}$ & ${ }^{*}$ \\
\hline Southern subtropical hill forest & ${ }^{*}$ & ${ }^{*}$ & ${ }^{*}$ \\
\hline Southern secondary moist mixed forest & ${ }^{*}$ & ${ }^{*}$ & ${ }^{*}$ \\
\hline West coast semievergreen & ${ }^{*}$ & ${ }^{*}$ & ${ }^{*}$ \\
\hline Moist bamboo brakes & ${ }^{*}$ & ${ }^{*}$ & ${ }^{*}$ \\
\hline Lateritic semievergreen forest & ${ }^{*}$ & ${ }^{*}$ & ${ }^{*}$ \\
\hline
\end{tabular}


deciduous type of forest (Table 2). It was seen that all the three species were distributed in all study locations, barring BWS, where T. malabaricus and $H$. hypnale were not recorded during the present study. This could be due to the anthropogenic activities in and around the sanctuary as human disturbances can affect the snakes in terms of their distribution (Greene 1988; Peterson 1990; Brown 1993; Parent \& Weatherhead 2000). Terrestrial and arboreal habitats differ profoundly in many ways including the types and amount of food availability, vulnerability to predators, and physical factors such as temperature and humidity. Those differences have resulted in many taxa becoming highly specialized for either terrestrial or arboreal life and rarely venturing to alternative habitat (Plummer 1981; Luiselli et al. 2000; Vilt et al. 2000). Trimeresurus malabaricus and T. gramineus remain camouflaged in the thick canopy of the trees at an average height of 3-5 m from the ground, which could help avoiding avian predators. Sometimes they were also encountered while crossing the roads at night hours during the monsoon. This could be due to the thigmothermic response to warm surfaces, such as asphalt roads at night in nocturnal crotalines (Klauber 1972). This excursion to the ground could be driven by the availability of prey, especially frogs which are important food of pit vipers and mate searching, pheromonal trail following may result in males traveling further and longer to locate females (Shine et al. 2004). Further, $H$. hypnale was occasionally sighted among small herbs exhibiting semi-arboreal habit. The occasional use of arboreal habitat offers a good opportunity for the snake as it might reduce the efforts or energy needed to thermoregulate or search prey. Similar observations are reported by Oliveira \& Martins (2001) and Shine et al. (2005). H. hypnale and T. gramineus preferred a broader range of altitude as compared to $T$. malabaricus, however T. malabaricus was also found at lower altitude in CWS suggesting that it is the ideal habitat with suitable hygrothermal profile and prey base which is the basic factor influencing distribution of these species. Some researchers (Campbell \& Solorzano 1992; Huang et al. 2007) consider ambient temperatures to be the most important environmental factor limiting the altitudinal distribution of reptiles.

The remarkable change in the shift in habitat by $H$. hypnale was seen during the present study, wherein it was observed that during post monsoon and winter they occupy the cashew plantations $(n=45)$ adjoining the PAs. It is mainly due to the leaf litter, thick bushes which provides ideal microhabitat, suitable hygrothermal conditions, prey availability, and predator avoidance. Cool and humid environment below leaf litter provides good microclimatic condition for the forest floor reptiles (Kumar 2001), which is the major prey base for pit vipers. According to Block \& Morrison (1998) leaf litter depth is an important factor in habitat selection in amphibians and reptiles. Since snakes are predatory in nature, therefore
Table 3. Observation of pit vipers in different study sites (Mean \pm SE)

\begin{tabular}{|l|c|c|c|}
\hline \multirow{2}{*}{ Study Area } & \multicolumn{3}{|c|}{ Number of individuals of each species } \\
\cline { 2 - 4 } & T. malabaricus & T. gramineus & H. hypnale \\
\hline CWS & $7.75(3.4)$ & $7.25(1.4)$ & $9.5(4.4)$ \\
\hline BWS & 0 & $2.75(1.8)$ & 0 \\
\hline MWS & $8(5)$ & $5.25(3.3)$ & $9.75(4.8)$ \\
\hline BMWS \& NP & $3.5(0.5)$ & $3.75(2.1)$ & $14.5(5.2)$ \\
\hline NWS & $3.25(1.3)$ & $4.75(2.9)$ & $7.75(5.1)$ \\
\hline
\end{tabular}

Table 4. Variation in the observation of pit vipers among different seasons in the Western Ghats of Goa (Mean \pm SE)

\begin{tabular}{|l|c|c|c|}
\hline \multirow{2}{*}{\multicolumn{1}{|c|}{ Species }} & \multicolumn{3}{|c|}{ Season } \\
\cline { 2 - 4 } & Summer & Monsoon & Winter \\
\hline T. malabaricus & $1.75(1)$ & $17(6.9)$ & $3.25(1.7)$ \\
\hline T. gramineus & $2(1.08)$ & $18.5(9.6)$ & $3(1.7)$ \\
\hline H. hypnale & $9.5(2.1)$ & $24.75(14)$ & $7.25(4.3)$ \\
\hline
\end{tabular}

their local distribution might be influenced by distribution of prey abundance (Dar et al. 2008). It was seen that all the three species exhibited patchy distribution during summer and winter, confined to areas in close proximity of water bodies, whereas, in monsoons they were distributed in all transects.

It was also seen that the abundance of all the three species varied in different seasons. The abundance was highest in monsoon compared to summer and winter. The highest abundance during monsoon was due to the suitable climatic conditions such as low temperature (22$24^{\circ} \mathrm{C}$ ), high humidity and rich prey base. In summer and winter the prey base (such as frogs) and suitable climatic conditions are restricted to patches in the vicinity of water bodies in the PAs. According to Sun et al. (2001) prey availability and abiotic factors, especially temperatures are the cues that drive seasonality in snakes.

It seems evident from the present study that pit vipers species are habitat specific and abiotic factors within the habitat such as seasonal changes in temperature and humidity, have influence on the distribution of these snakes. Hence, the protection of habitat is an important aspect in conservation of these species.

\section{REFERENCES}

Bhide, K. (2001). Venomous Snakes: Correspondence Course in Basic Herpetology, Chapter IV, Bombay Natural History Society, Mumbai, pp.17-20.

Block, W.M. \& M. Morrison (1998). Habitat relationship of amphibians and reptiles in California, Woodlands. Journal of Herpetology 32: 51-60.

Brown, W.S. (1993). Biology, status and management of the timber rattlesnake (Crotalus horridus): a guide for 
conservation. Society for the Study of Amphibians and Reptiles Herpetologica 22: 1-78.

Campbell, J.A. \& A. Solorzano (1992). The distribution, variation and natural history of the middle American montane pitviper, Porthidium godmani, pp. 223-250. In: Campbell, J.A. \& E.D. Brodie Jr., (eds.). Biology of Pitvipers. Selva Tyler Press, Texas.

Champion, H.G. \& S.K. Seth (1968). A Revised Survey of the Forest Types of India. Government of India Press, Delhi, 404pp.

Dahanukar, N. \& A. Padhye (2005). Amphibian diversity and distribution in Tamhini, northern Western Ghats, India. Current Science 88: 1496-1501.

Daltry, J.C., T. Ross, R.S. Thorpe \& W. Wuster (1998). Evidence that humidity influences snake activity patter: a field study of the Malayan Pit Viper Calloselasna rodostoma. Ecography 21: 25-34.

Daniel, J.C. (2002). The Book of Indian Reptiles \& Amphibians. Oxford University press, New Delhi, 238pp.

Dar, T.A., J.A., Khan, B. Habib, S.P.S. Kushwaha \& N. Mendiratta (2008). Assessment of Herpetofauna assemblage in phakot and pathri Rao watershed areas, Uttarakhad, India. International Journal of Ecology and Environmental Sciences 34(2): 207-213.

Greene, H.W. (1988). Antipredator mechanisms in reptiles, pp. 1-152. In: Gans, C. \& R.B. Huey (eds.). Biology of The Reptilia - Vol 16. Liss, New York.

Heatwole, H. (1982). A review of structuring in herpetofaunal assemblages, pp. 1-19. In: Scott, N.J.Fr. (ed.). Herpetological communities: a symposium of the society for the study of Amphibians and Reptiles and the herpetologists league, August 1977. US Fish and wildlife service. Reports pg 13.

Huang, S.M., S.P. Huang, Y.H. Chen \& M.C. Tu (2007). Thermal tolerance and altitudinal distribution of three Trimeresurus snakes (Viperidae: Crotalinae) in Taiwan. Zoological Studies 46(5): 592-599.

Jha, C.S., C.B.S. Dutt \& K.S. Bawa (2000). Deforestation and land use changes in the Western Ghats, India. Current Science 79: 231-238.

Joshi, V.C. \& M.K. Janarthanam (2004). The diversity of life forms type, habitat preference \& phenology of the endemics in the Goa region of Western Ghats, India. Journal of Biogeography 31: 1227-1237.

Khaire, N. (2006). A Guide to the Snakes of Maharashtra, Goa and Karnataka. Indian Herpetological Society. 'USANT', Maharashtra, India, 104-114pp.

Klauber, L.M. (1972). Rattlesnakes: Their Habits, Life Histories and Influence on Mankind. University of California, Berkeley, 740pp.

Kumar, A., R. Chellam, B.C. Choudhary, D. Mundappa, K. Vasudevan, N.M. Ishwar \& B. Noon (2001). Impact of rainforest fragmentation on small mammals and herpetofauna in the Western Ghats India. Final project report, Wildlife Institute of India.

Kumar, A., S. Walker \& S. Molur (1998). Prioritization of Endangered Species. Report submitted to World Wildlife Fund for Nature-India.
Luiselli, L., F.M. Angelici \& G.C. Akani (2000). Large elapids and arboreality: The ecology of Jamesons Green Mamba (Dendroaspis jameson) in an Afrotropical forested region. Contribution to Zoology 69: 147-155.

Menon, S. \& K.S. Bawa (1997). Applications of Geographic Information Systems (GIS), remote-sensing, and a landscape ecology approach to biodiversity conservation in the Western Ghats. Current Science 73: 134-145

Murthy, T.S.N. (1990). Records of The Zoological Survey of India: Illustrated Guide to The Snakes of The Western Ghats, India. Zoological Survey of India, Calcutta, 58-63pp.

Myer, N. (1990). The biodiversity challenge: Expanded hot spots analysis. Environmentalist 10: 243-256.

Myers, N., R.A. Mittermeier, C.G. Mittermeier, G.A.B. da Fonseca \& J. Kent (2000). Biodiversity hotspots for conservation priorities. Nature 403: 853-858.

Oliveira, M.E. \& M. Martins (2001). When and where to find a pit viper: activity patterns and habitat use of the Lancehead, Bothrops atrox, in central Amazonia, Brazil. Herpetological Natural History 8(2): 101-110.

Parent, C. \& P.J. Weatherhead (2000). Behavioral and life history responses of eastern massasauga rattlesnakes (Sistrurus catenatus catenatus) to human disturbance. Oecologia 125:170-178.

Peterson, A. (1990). Ecology and management of a timber rattlesnake (Crotalus horridus L.) population in south-central New York State. Museum Bulletin 471: 255-261.

Plummer, M.V. (1981). Habitat utilization, diet and movement of a temperate arboreal snake (Opheodrys aestivus). Journal of Herpetology 15: 425-432.

Shine, R., M. Lemaster, M. Wall, T. Langkilde \& R. Mason (2004). Why did the snake cross the road? Effects of Roads on movement and location of mates by garter snakes (Thamnophis sirtalis parietalis). Ecology and Society 9(1): 9

Shine, R., M. Wall, T. Langkilde \& R.T. Mason (2005). Scaling the heights: thermally driven arboreality in garter snakes. Journal of Thermal Biology 30: 179-185.

Smith, M.A. (1943). Reptiles and Amphibia: The fauna of British India, Ceylon and Burma, Vol III - Serpentes. Today \& Tommorow's Printers \& Publishers, New Delhi, 494-526pp.

Sun, L., R. Shine, D. Zhao \& Z. Tang (2001). Biotic and abiotic influences on activity patterns of insular pit-vipers (Gloydius shedaoensis, Viperidae) from north-eastern China. Biological Conservation 97: 387-398.

Vasudevan, K., A. Kumar \& R. Chellam (2001). Structure and composition of rainforest floor amphibian communities in Kalakad-Murdanthurai Tiger Reserve. Current Science 80: 406-412.

Vilt, L.J., S.S. Sartorias \& T.C.S. Avila-Pires, M.C. Esposito \& D.B. Miles (2000). Niche segregation among sympatric Amazonian teiid lizards. Oecologia 122: 410-420.

Whitaker, R. (1969). Common Indian Snakes: A Field Guide. Bombay Natural History Society, 183pp.

Whitaker, R. \& A. Captain (2004). Snakes of India: The Field Guide. Draco Books, Chennai, 481pp. 